\title{
Effect of Operational Parameters on Performance of Small Tractor Operated Intercultivator cum Fertilizer Applicator in Cotton Crop
}

\author{
Anandraddi Jumanal $^{1 *}$, Sushilendra ${ }^{2}$, K.V. Prakash ${ }^{3}$, \\ V. Raghavendra ${ }^{3}$ and G.S. Yadahalli ${ }^{4}$ \\ ${ }^{1}$ Department of FMPE, UAS, Raichur, Karnataka, India \\ ${ }^{2}$ Department of FMPE, CAE, UAS, Raichur, Karnataka, India \\ ${ }^{3}$ Department of REE, CAE, UAS, Raichur, Karnataka, India \\ ${ }^{4}$ Department of Agronomy, College of Agricultural, UAS, Raichur, Karnataka, India \\ *Corresponding author
}

\begin{tabular}{|c|}
\hline Keywords \\
\hline $\begin{array}{l}\text { Operational parameters, } \\
\text { Small tractor, } \\
\text { Intercultivator, Fertilizer } \\
\text { Applicator, Cotton crop }\end{array}$ \\
\hline Article Info \\
\hline $\begin{array}{l}\text { Accepted: } \\
18 \text { October } 2018 \\
\text { Available Online: } \\
10 \text { November } 2018\end{array}$ \\
\hline
\end{tabular}

A B S T R A C T

Intercultivation and fertilizer application are an important practice to be carried out during the different stages of crop growth. Delay and negligence of intercultivation and fertilizer application operation reduces the crop yield. In present scenario the availability of enough labour and the bullock power for intercultural and fertilizer application operations do not synchronize with the ideal season. Hence, majority of the farmers could not complete the intercultural and fertilizer application operations in time. Considering these points related to intercultivation and fertilizer application an attempt was made to develop equipment which would be able to perform both the operations of intercutivation and fertilizer application simultaneously and more efficiently in row crops. An experiment was conducted to evaluate the field performance of developed an intercultivator cum fertilizer applicator for small tractor with high clearance was carried out Main Agriculture research station Raichur. The modified small tractor with the developed intercultivator cum fertilizer applicator prototype was evaluated in terms of weeding efficiency, plant damage and draft. The performance of small tractor operated intercultivator cum fertilizer applicator was evaluated at three different forward speeds $\left(1.5,2.0\right.$ and $2.5 \mathrm{~km} \mathrm{~h}^{-1}$ ) with three soil moisture contents $(12 \% \pm 1,14 \% \pm 1$ and $16 \% \pm 1)$ for three types of blades (Straight type, V-shape type and crescent type) in cotton crops. Recommended fertilizer application rate of $50 \mathrm{~kg} \mathrm{ha}^{-1}$ was observed at a forward speed of $2.0 \mathrm{~km} \mathrm{~h}^{-1}, 0.078 \mathrm{~ms}^{-1}$ of feed shaft and $3 / 4^{\text {th }}$ of hopper level and these parameters were as considered optimum for applying fertilizer. Both the intercultivation and fertilizer application operations can be simultaneously done in single operation. The better performance of small tractor operated intercultivator cum fertilizer applicator was achieved at a forward speed of $2.0 \mathrm{~km} \mathrm{~h}^{-1}$ with a moisture content of $14 \% \pm 1$ for $\mathrm{V}$-shape type blade.

\section{Introduction}

Agriculture is one of the major sectors in Indian economy. Nearly 60 per cent of the population depends on agriculture and it is considered as backbone of the country. Cotton 'The white gold' is one of the most important commercial crops playing a key role in the 
economical and social affairs of the country. It sustains the country's cotton textile industry. Which is perhaps the largest segment of organized industries in the country. India ranks third in the world in production of cotton crop.

Mechanical weed control can be defined as a physical activity that inhibits unwanted plant growth. Mechanical weeding method performs better than other methods. Mechanical or manual weed control techniques manage weed populations through physical methods that remove, injure, kill, or make the growing conditions unfavorable. Mechanical weeders range from basic hand tools to sophisticated tractor driven or self-propelled machines. Such weeders include cultivation tools such as hoes, harrows, tined implements, brush weeders, cutting tools like mowers and strimmers. Mechanical weeding is preferred to chemical method because weedicides are not only expensive but some of the weedicides are injurious to crops and human beings. Besides mechanical weeding keeps the soil surface loose by producing the soil mulch which results in better aeration and moisture conservation (Padole, 2007).

Availability and quality of matching equipment for small mechanical power sources is a major concern in general and weeding equipment in particular. Any new developments in this aspect using mini tractor will reduce the drudgery of small land holders besides meeting timeliness of operations where, mostly family labour is engaged. In majority of crops, the intercultural operation accompanies with top dressing of fertilizer, mechanization enhances input use efficiency also.

The fertilizer application is also important with respect to the soil health. The fertilizer application 30, 60 and 90 days after sowing (DAS) is recommended in the package of practice for field crops for supplying required amount of nutrients (NPK). The fertilizer application is done traditionally by broadcasting and hill dropping which requires more human effort. The weeding is generally done manually and with the help of bullock drawn implements which becomes costly because of lower work output.

To overcome these problems, there was a need for developing the equipment which would be beneficial to the farmer for the intercultivation and fertilizer application operations. Considering these points related to intercultivation and fertilizer application an attempt was made to develop equipment which would be able to perform both the operations of intercutivation and fertilizer application simultaneously and more efficiently in row crops. The traditional four wheel small tractors with ground clearance of around 260 to $300 \mathrm{~mm}$ cannot move in cotton field as the plants are about 500 to $950 \mathrm{~mm}$ height in 60-90 days after sowing. So it was felt necessary to increase the ground clearance of the small tractor to make it suitable for intercultivation during the later stages of crop growth.

To overcome the above problems, it was decided to develop suitable attachments for increasing the ground clearance of small tractor to carry out intercultivation and fertilizer application operations simultaneously.

At present, the ground clearance existing in small tractor is very less and suitable matching weeding attachment is essential to target the weeds. In Raichur district, cotton crops are being common field crops and weeding operation in such field crops challenges the weeding operation. Fertilizer application for better plant growth is also need of hour. Keeping in view of the above facts, the present research work has been under taken. 


\section{Materials and Methods}

A small tractor Mahindra and Mahindra make Yuvraj 215 model was selected as prime mover for the development intercultivator cum fertilizer applicator. The small tractor was selected as a prime mover for of intercultural and fertilizer applicator due to its greater advantages of being smaller in size, less weight, easy manoeuvrability and would cause less compaction of soil during its movement on soil surface. According to agronomic requirements, for cotton crops, the commonly adopted row to row spacing by the farmers of this region was $1200 \mathrm{~mm}$, respectively. In general the intercultural and fertilizer application operations were carried up to 2030 days after sowing (DAS), 45-60 DAS and $80-90$ DAS. By this time the red gram plant height would be 600 to $950 \mathrm{~mm}$ in a normal monsoon season. Considering plant geometry of selected crops at the time of intercultivation after 30 DAS, 60 DAS and 90 DAS and to make small tractor suitable for intercultivation operation, best option available for the designer was changing its track width to allow a single row to pass under the centre line of the tractor and reset the implement frame and working tools on either side of the under pass row with due allowances and raise small tractor ground clearance. Accordingly, the small tractor front, rear wheel track widths as well as ground clearance were increased to accommodate the plant geometry of selected crops at different stages of growth. Allowing one crop row to pass under centre line of the tractor and $150 \mathrm{~mm}$ as zone of clearance for maneuverability from either side of the row to tyre outer edges, the track width requirements would work out be $1340 \mathrm{~mm}$. The existing ground clearance of the tractor was increased with the developed high clearance attachments using mild steel as a structure. The tractor was lifted up to height of $830 \mathrm{~mm}$ using front and rear legs of front axle and rear axle. The drive from the tractor rear axle was transferred to the rear wheels using chain and sprocket arrangement for both the rear wheels. The front legs of front wheels and rear legs of rear wheels were connected using horizontal bar for proper supporting and load distribution.

\section{Fabrication of small tractor operated intercultivator cum fertilizer applicator}

The prototype small tractor operated intercultivator cum fertilizer applicator was fabricated. The prototype small tractor operated intercultivator cum fertilizer applicator was consisted of tool main frame, blades, shanks, tractor battery operated variable speed motor, fertilizer box, fertilizer metering mechanism (gear type), fertilizer tubes and three point hitch.

\section{Testing and evaluation small tractor operated intercultivator cum fertilizer applicator}

\section{Laboratory performance test for fertilizer metering device}

One of the basic functions of this implement was the fertilizer rate. Hence, the fertilizer application was an important criterion for its performance evaluation. The fertilizer application rate was examined in the laboratory. For determining application rate feed shaft was operated at $0.078 \mathrm{~ms}^{-1}, 0.098$ $\mathrm{ms}^{-1}$ and $0.12 \mathrm{~ms}^{-1}$ using speed regulator with respect to forward speed of tractor and the effect of different combinations of hopper capacity on application rate was also checked The feed shaft speed was controlled using speed regulator (12V DC motor with variable speed drive).

\section{Speed of operation}

The tractor was operated at selected speeds of $1.5,2.0$ and $2.5 \mathrm{~km} \mathrm{~h}^{-1}$ for intercultural operation. Before conducting trials the travel 
speed of tractor was calibrated for required forward speed for intercultural operation. These travels speeds were achieved by adjusting engine throttle position and gear setting. For calibration of speed of operation, a test trial conducted in same field condition in order to avoid errors. The tractor was operated at all the gear and at three different throttle lever position. Finally it was concluded that at the $3 / 4^{\text {th }}$ the throttle lever position, low speed gear ratios of $\mathrm{L}_{1}, \mathrm{~L}_{2}$ and $\mathrm{L}_{3}$ gave forward speeds of $1.5,2.0$ and $2.5 \mathrm{~km} \mathrm{~h}^{-1}$, respectively.

For calculating traveling speed of two poles $20 \mathrm{~m}$ apart was placed approximately in middle of the test run. On the opposite side also two poles were placed in similar position, $20 \mathrm{~m}$ apart so that four poles forms corners of rectangle, parallel on long side of the plot. The speed was calculated from the time required for machine to travel the known distance (20 m) between two poles. Average of such readings was taken to calculate the travelling speed of small tractor operated intercultivator cum fertilizer applicator. The forward speed of operation was calculated by observing the distance travelled and time taken by following formula (Mehta et al., 2005).

$S=\frac{L}{t}$

Where,

$\mathrm{S}=$ forward speed of machine, $\mathrm{ms}^{-1}$

$\mathrm{L}=$ distance travelled, $\mathrm{m}$

$\mathrm{t}=$ time taken, $\mathrm{s}$

\section{Draft}

Draft was measured using load cell. A small tractor operated intercultivator cum fertilizer applicator with high clearance attachment (A) and this tractor was towed by another tractor (B) through a load cell. The draft was measured by keeping tractor $\mathrm{A}$ is in neutral gear condition. The draft of the implement was measured with load and without load.

Total draft exerted on the small tractor operated intercultivator cum fertilizer applicator with high clearance attachment was computed using the formula. Anon. (1995)

$\mathrm{D}=\mathrm{D}_{1}-\mathrm{D}_{2}(2)$

Where,

$\mathrm{D}=$ Draft of small tractor operated intercultivator cum fertilizer applicator with high clearance attachment, $\mathrm{kg}$

$\mathrm{D}_{1}=$ Draft of intercultivator under working condition, $\mathrm{N}$

$\mathrm{D}_{2}=$ Draft of intercultivator with implement under lifted position (no load condition), $\mathrm{N}$

\section{Weeding efficiency}

To determine the weeding efficiency, a square frame of $1 \times 1 \mathrm{~m}$ was thrown in the field randomly at six different places in the test plot and the number of weeds was counted before operation and number of weeds left after operation. The weeding efficiency of the intercultivator was calculated by the following equation.

$\mathrm{w}_{\mathrm{e}}=\frac{\mathrm{w}_{\mathrm{b}}-\mathrm{W}_{\mathrm{a}}}{\mathrm{w}_{\mathrm{b}}} \times 100$

Where,

$\mathrm{W}_{\mathrm{e}}=$ weeding efficiency, $\%$

$\mathrm{W}_{\mathrm{b}}=$ number of weeds counted per square meter before operation

$\mathrm{W}_{\mathrm{a}}=$ number of weeds counted per square meter after operation 


\section{Plant damage}

Plant damage was calculated by counting the number of plants in $10 \mathrm{~m}$ rows before weeding and number of the plant damaged in the same $10 \mathrm{~m}$ row length after weeding (Biswas and Yadav, 2004).

Plant damge $=\frac{P-Q}{P} \times 100$

Where,

$\mathrm{Q}=$ total number of plants damaged after weeding in $10 \mathrm{~m}$ rows

$\mathrm{P}=$ total number of plants before weeding in $10 \mathrm{~m}$ rows

\section{Results and Discussion}

\section{Calibration of fertilizer applicator under laboratory condition}

The fertilizer rate increased with increase in speed of feed shaft of fertilizer metering unit. It was evident from Figure 1, 2 and 3. That fertilizer rate was maximum at $0.12 \mathrm{~ms}^{-1}$ of feed shaft while minimum was obtained at $0.078 \mathrm{~ms}^{-1}$ of feed shaft. The fertilizer rate increased with increase in speed of feed shaft due to the fact that, the quantity of fertilizer delivery per revolution of feed shaft was increased with increase in speed of feed shaft. These trends were in agreement with findings of Sharma and Pannu (2013). The recommended fertilizer rate of $50 \mathrm{~kg} \mathrm{ha}^{-1}$ was observed at forward speed of $2.0 \mathrm{~km} \mathrm{~h}^{-1}, 0.078$ $\mathrm{ms}^{-1}$ of feed shaft and $3 / 4^{\text {th }}$ of hopper level and these parameters were as considered optimum for field evaluation.

The fertilizer application rate was maximum at full of fertilizer level in the hopper while it was minimum at half of fertilizer level in the hopper. The fertilizer application rate decreased with decrease in fertilizer level in hopper. As the fertilizer level in hopper was decreased the chances of fertilizer entering in the spur wheels grooves was also decreased (Sharma and Pannu, 2013).

The fertilizer application rate was also affected by the forward speed of the tractor as drive to operate fertilizer feed shaft was taken from a DC motor operated by tractor battery. The fertilizer application rate was minimum at higher forward speed. Lowest fertilizer application rate was observed at high forward speed due to decrease in exposure time for the spur wheels to grooves to deliver the fertilizer (Singh and Nikhade, 2014)

Effect of operational parameters on performance of small tractor operated intercultivator cum fertilizer applicator in cotton crop

The effect of operational parameters viz. soil moisture content, forward speed, and type of blade on draft, weeding efficiency and plant damage of operated intercultivator cum fertilizer applicator in cotton crop are discussed below.

\section{Draft}

The effect of soil moisture content and forward speed on draft with different types of blades are presented in Figure 4 to 6. It was observed that, the draft increased as the forward speed increased for all the soil moisture contents. However less draft were observed at forward speed of $1.5 \mathrm{~km} \mathrm{~h}^{-1}$ for the V-shape type blade for all soil moisture contents.

The draft was increased as speed of operation increases due to rapid acceleration of any soil that was moved appreciably. As the acceleration forces increases, it increased the normal loads on soil engaging surfaces there 
by increasing the frictional resistance and kinetic energy was imparted to the soil (Kepner et al., 2005). The results also indicated that, the draft was decreased as the soil moisture content increased in the range of $12 \% \pm 1$ to $14 \% \pm 1$. The decrease in the draft may be due to lower soil reaction forces at higher soil moisture content operation (Hunt 1977) as the soil moisture content increased from $12 \% \pm 1$ to $14 \% \pm 1$. This may be due to the lubricating effect of moisture films surrounding soil particles and also to a decrease in soil strength imparted by the moisture. The draft was increased again when the moisture content was more than $16 \% \pm 1$. It may due to the increase in friction of coefficient with the increase moisture content was explained by the growth in the forces of molecular attraction of the soil particle to the surface. With increase in unit pressure on the surface of contact, adhesiveness increased, which depend on the furrow slice weight. Therefore, increase in frictional coefficient and adhesiveness might be the reason for higher draft at higher soil moisture.

Therefore, the minimum draft was observed at a forward speed of $2.0 \mathrm{~km} \mathrm{~h}^{-1}$ for the $\mathrm{V}$-shape type blade for $14 \% \pm 1$ of soil moisture content as compared to others types of blades selected for present study. The reason for less draft for V-shaped blade was mainly due to its shape, apex angle and self-cleaning effect as compared to other two types of blades. More draft values were recorded for the straight blade as there was no self-cleaning effect in the straight blade which resulted in poor scouring of soil over the blade and frequent clogging of straight blade with weeds and soil might be the reason for higher draft values. The results are in agreement with the findings of Guruswamy (1985a).

The crescent type of blade recorded moderate values of draft for all the forward speeds and moisture contents.

\section{Weeding efficiency}

The effect of soil moisture content and forward speed on weeding efficiency with different types of blades for cotton crop have been presented in Figure 7 to 9. It was observed that, the weeding efficiency increased with increasing forward speed from 1.5 to $2 \mathrm{~km} \mathrm{~h}^{-1}$ there after it was decreased as the forward speed increased for all the soil moisture content, the similar trend was observed with all the three types of blades. However, higher weeding efficiency is observed at forward speed of $2.0 \mathrm{~km} \mathrm{~h}^{-1}$ for the V-shape type blade for all soil moisture contents. It was also observed that, as the speed of operation increased from 1.5 to 2.0 $\mathrm{km} \mathrm{h}^{-1}$, the weeding efficiency of weeding unit is increased. It may due better interaction between weeding tool with soil. At higher forward speed, less per cent of weeding efficiency was noticed and it may due to less time for interaction between weed and tool. So higher forward speed $2.5 \mathrm{~km} \mathrm{~h}^{-1}$ recorded less per cent of weeding efficiency. Hence, the forward speed of $2.0 \mathrm{~km} \mathrm{~h}^{-1}$ was found to be optimum for satisfactory weeding operation. Weeding efficiency increased with the increase in forward speed. Similar findings were reported by Rajshekar (2002) and Manuwa et al., (2009).

The weeding efficiency was found higher in $\mathrm{V}$-shape type of blade due to the easy penetration ability, self-cleaning ability and also increased soil inversion capacity of the blade as compared to straight and crescent type of blades. Similar findings were reported by Guruswamy (1985a). The test results indicated that weeding efficiency was more in case of $12 \% \pm 1$ and $14 \% \pm 1$ soil moisture contents when compared to $16 \% \pm 1$ soil moisture content. Therefore soil moisture content of $14 \% \pm 1$ was considered optimum value for performing intercultivation operation. Similar findings reported by Mallikarjuna (2017) and Yadav et al., (2007). 
Fig.1 Effect of speed of feed shaft (A) and forward speed (B) on fertilizer application Rate for full level

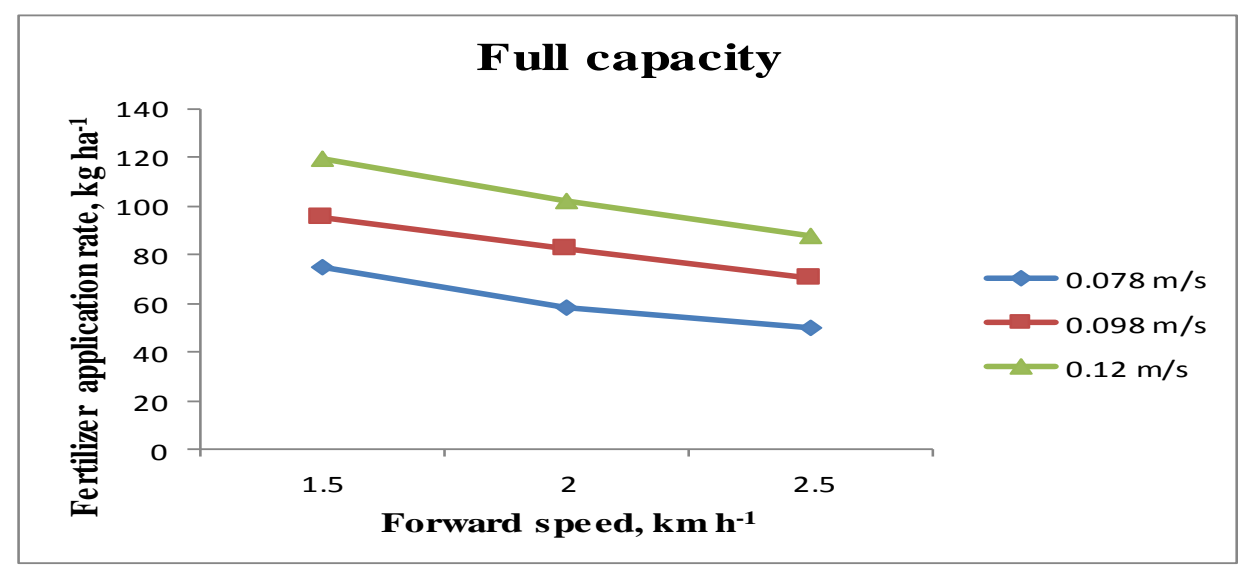

Fig.2 Effect of speed of metering shaft (A) and forward speed (B) on fertilizer application rate for $3 / 4^{\text {th }}$ level

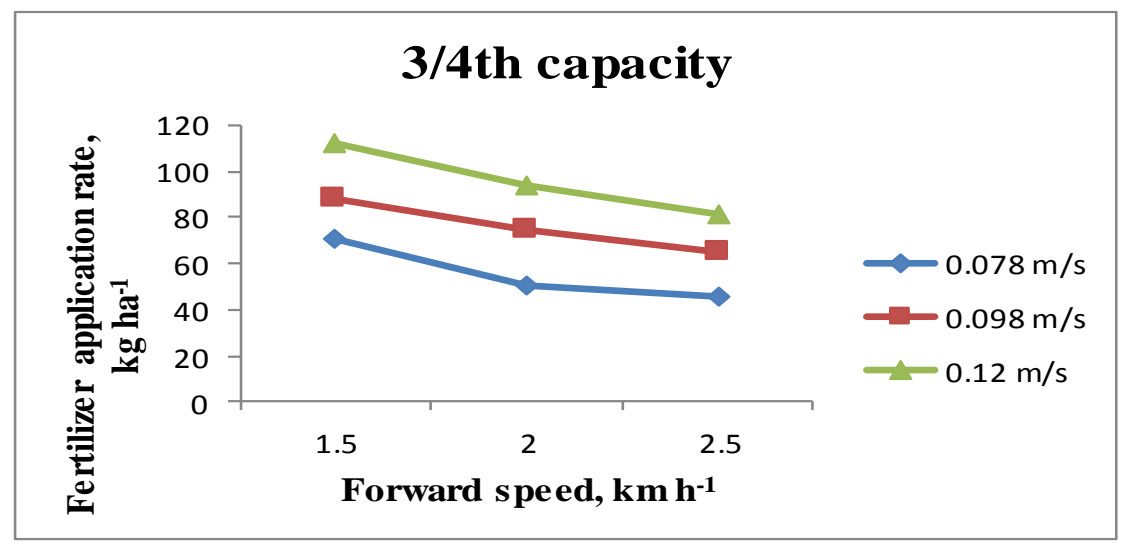

Fig.3 Effect of speed of metering shaft (A) and forward speed (B) on fertilizer application rate for half level

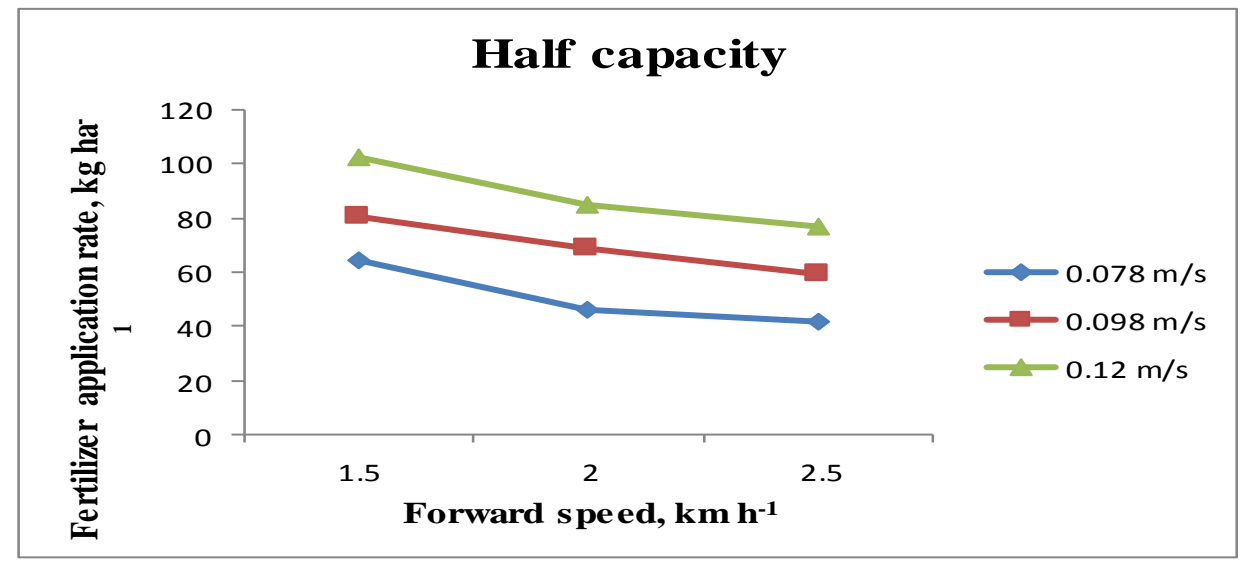


Fig.4 Effect of soil moisture content (A) and forward speed (B) on draft for straight blade in cotton crop

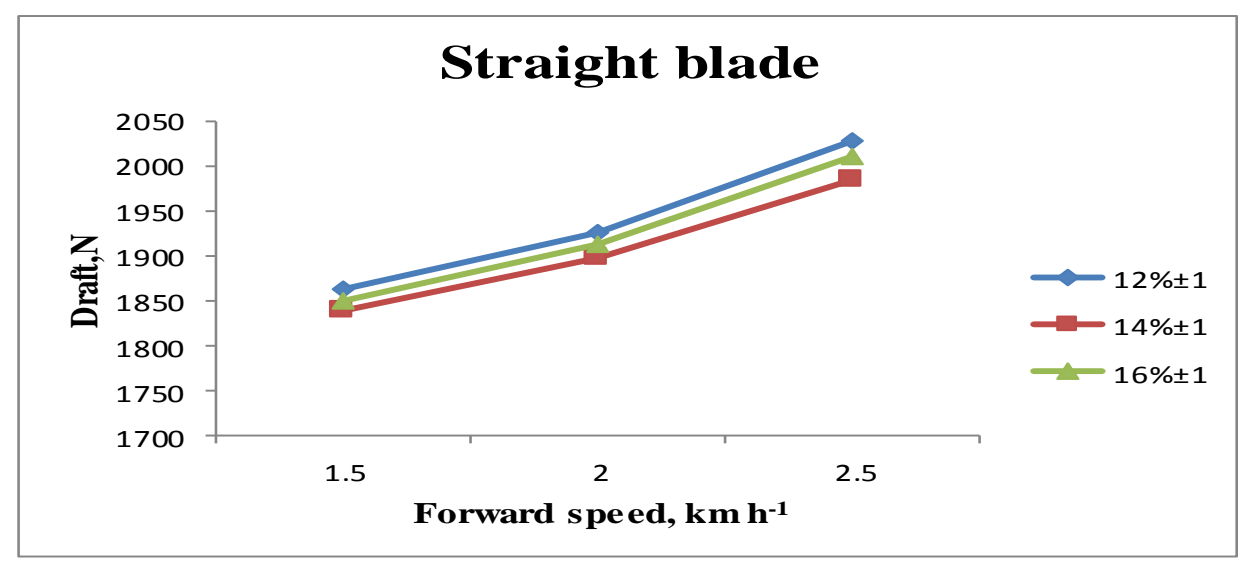

Fig.5 Effect of soil moisture content (A) and forward speed (B) on draft for V-shape blade in cotton crop

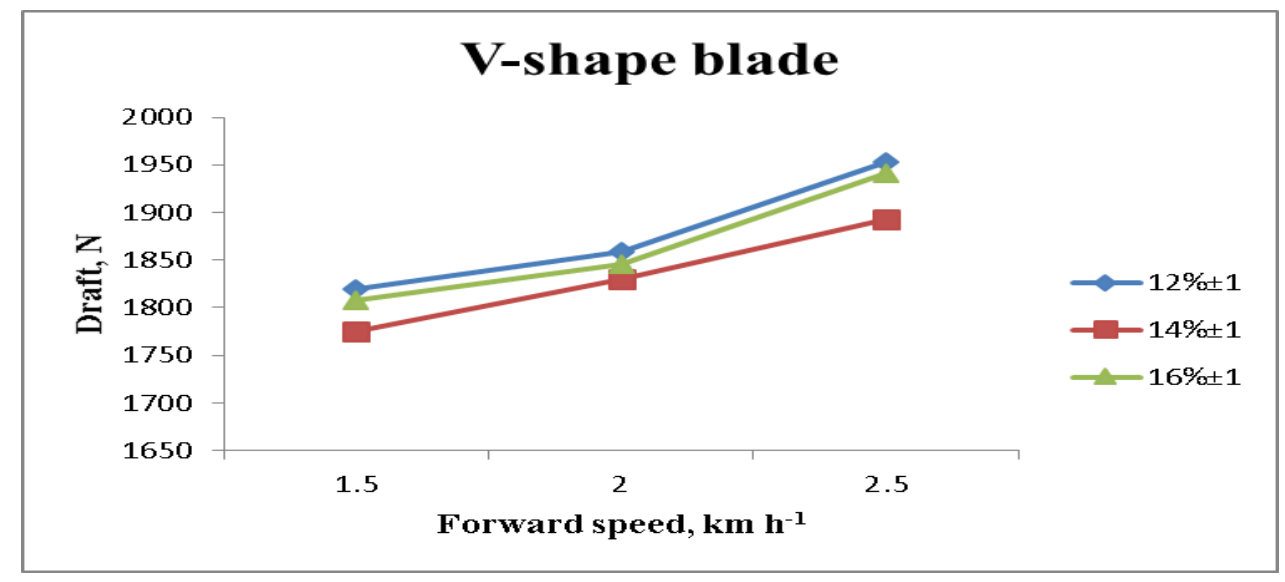

Fig.6 Effect of soil moisture content (A) and forward speed (B) on draft for crescent blade in cotton crop

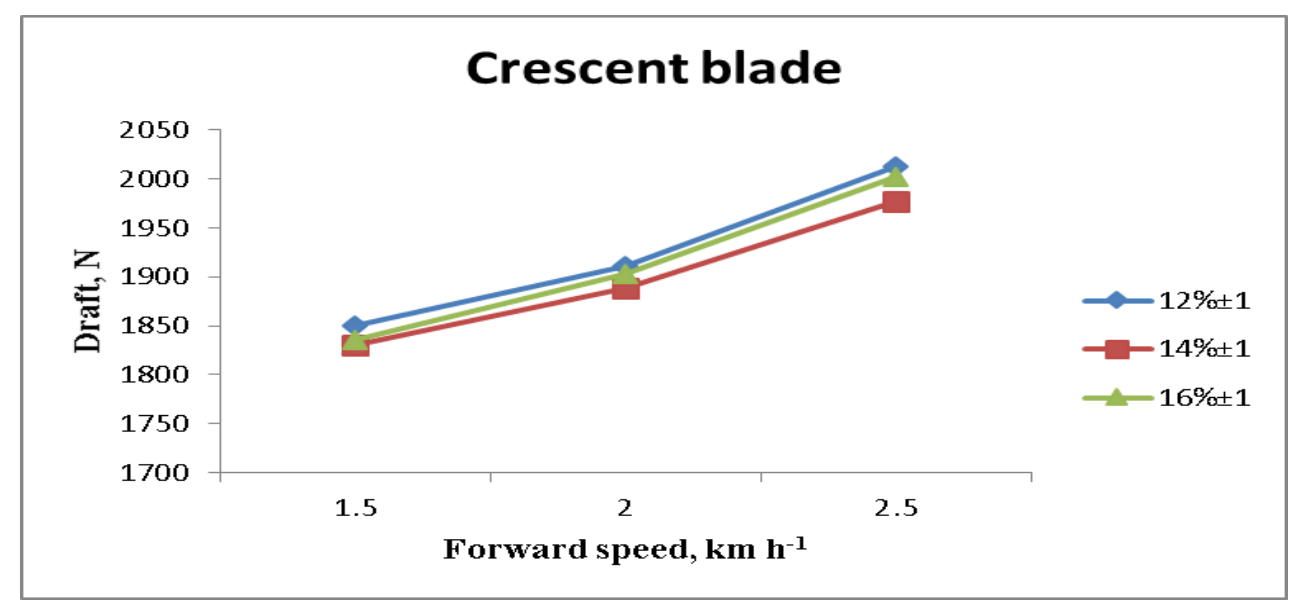


Fig.7 Effect of soil moisture content (A) and forward speed (B) on weeding efficiency for straight blade in cotton crop

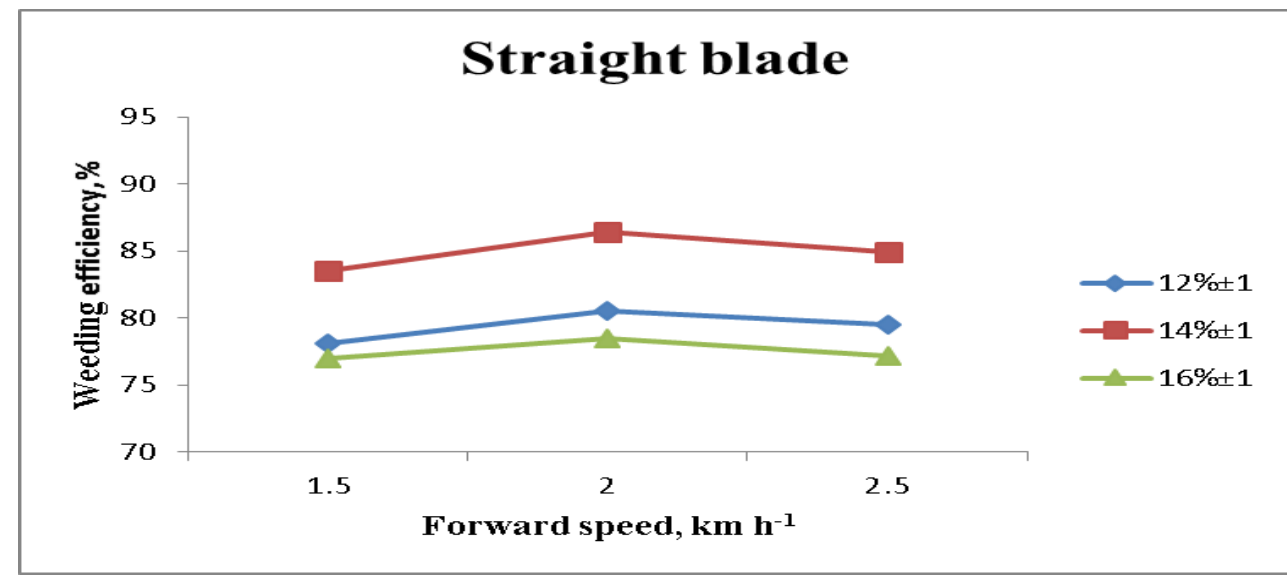

Fig.8 Effect of soil moisture content (A) and forward speed (B) on weeding efficiency for Vshape blade in cotton crop

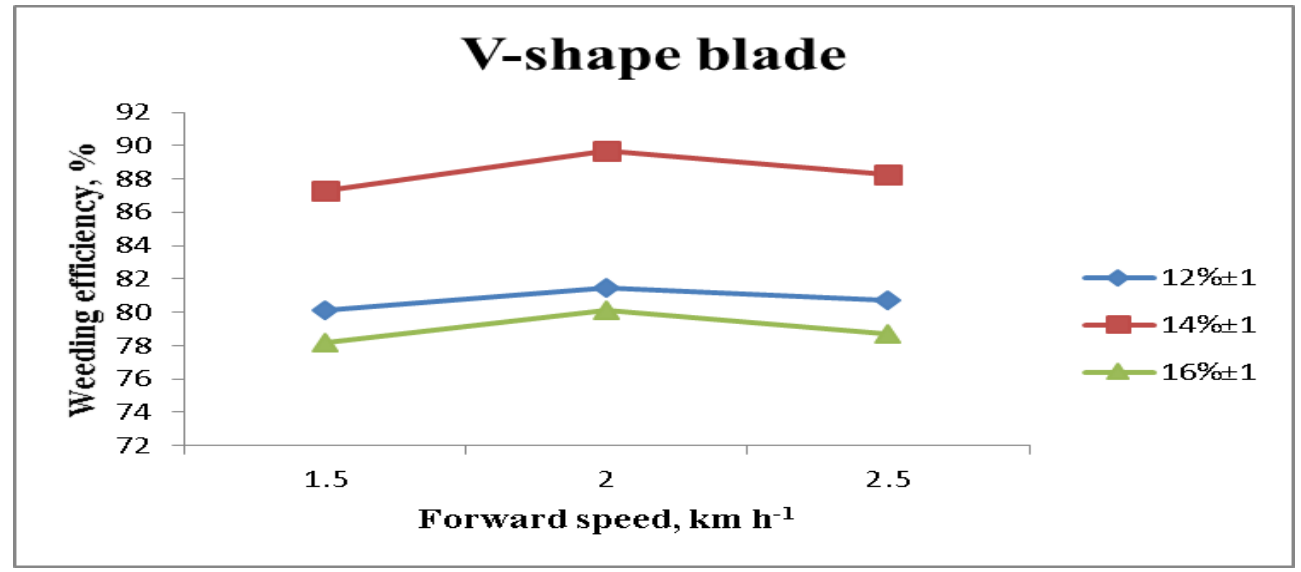

Fig.9 Effect of soil moisture content (A) and forward speed (B) on weeding efficiency for crescent blade in cotton crop

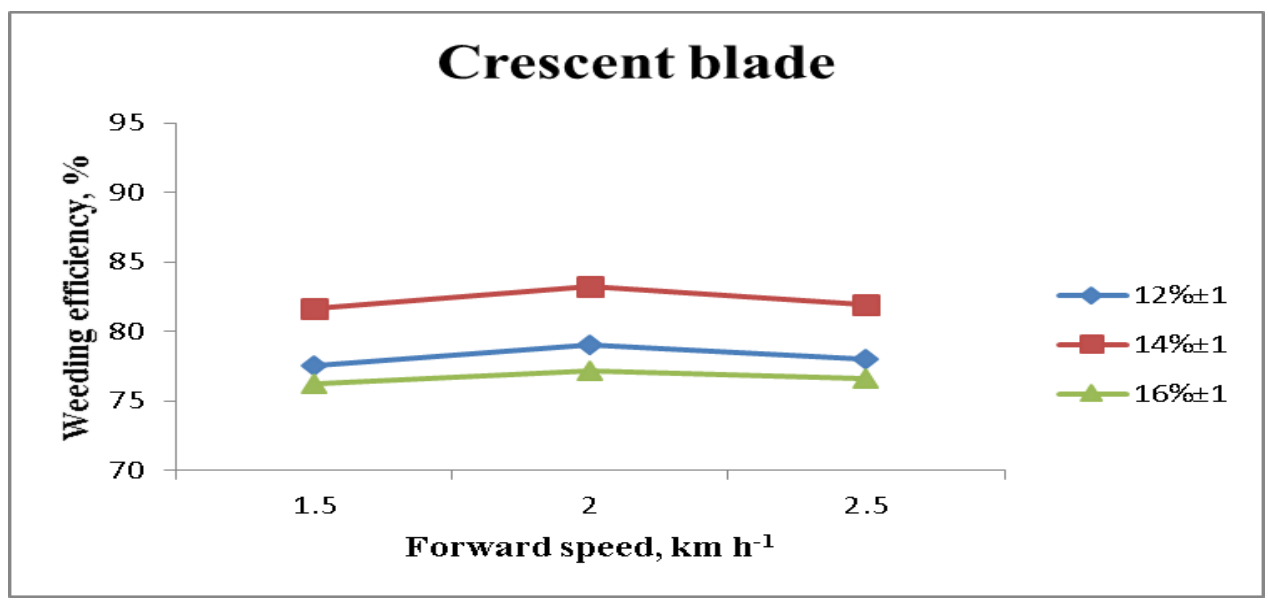


Fig.10 Effect of soil moisture content (A) and forward speed (B) on plant damage for straight blade in cotton crop

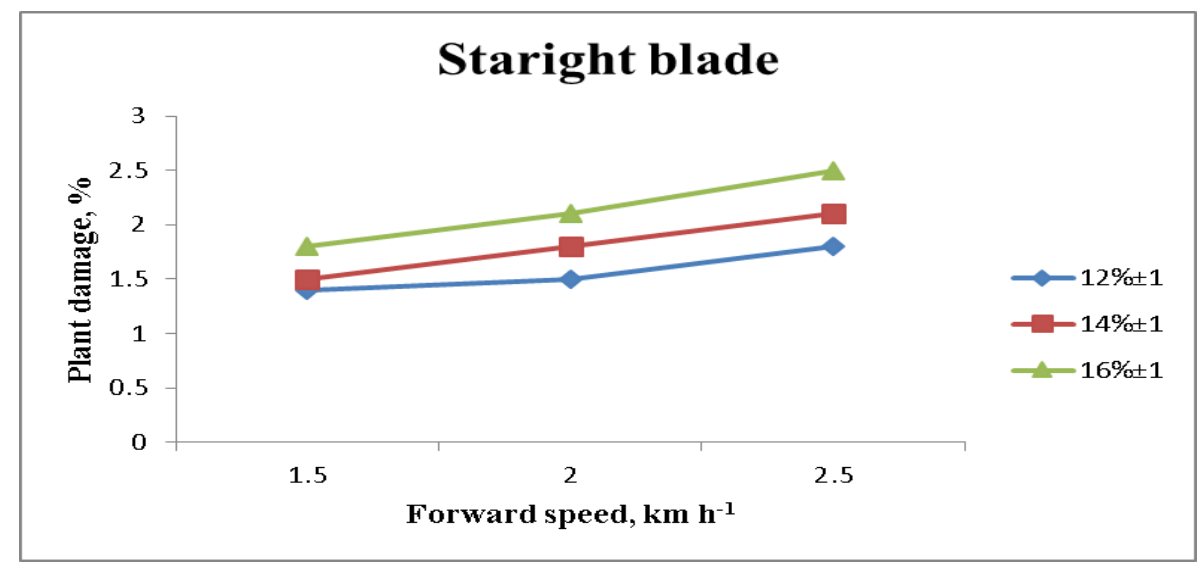

Fig.11 Effect of soil moisture content (A) and forward speed (B) on plant damage for V-shape blade in cotton crop

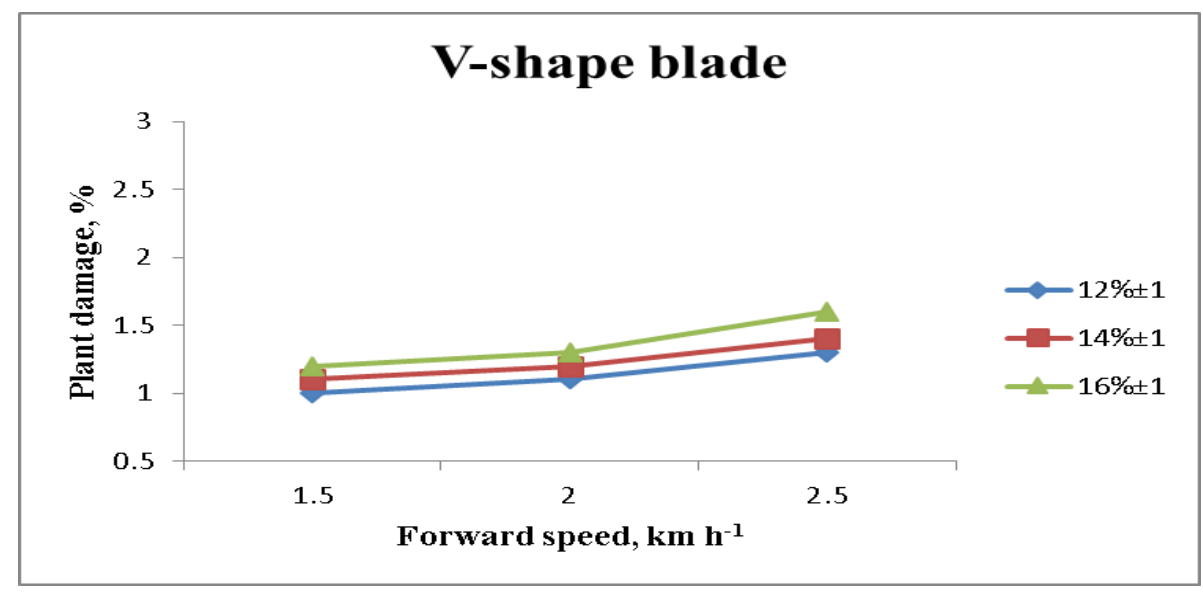

Fig.12 Effect of soil moisture content (A) and forward speed (B) on plant damage for crescent blade in cotton crop

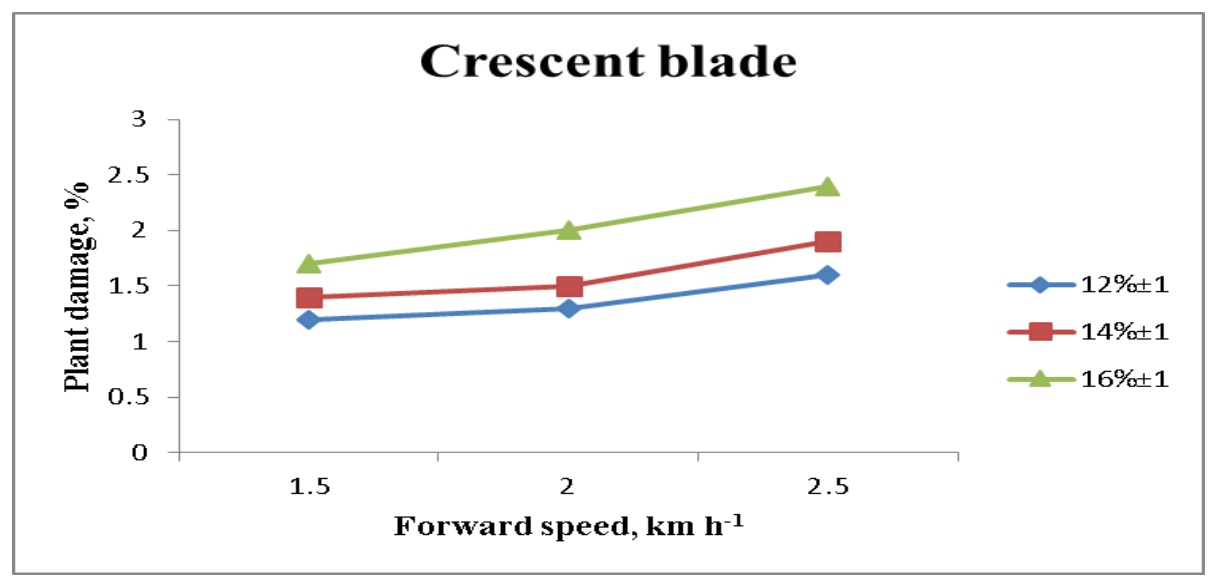


Plate.1 Performance evaluation of small tractor operated intercultivator cum fertilizer applicator in cotton crop
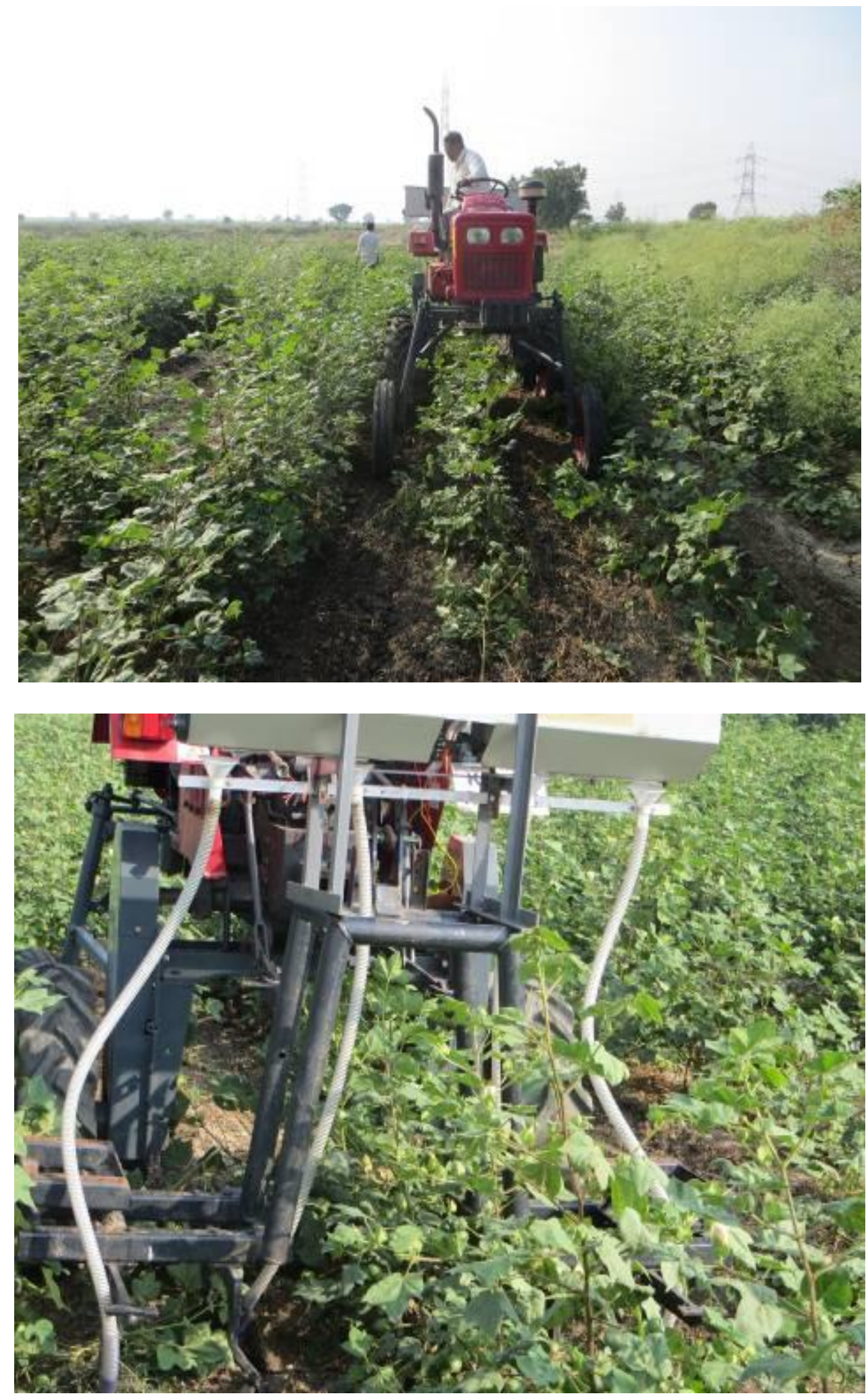


\section{Plant damage}

The effect of soil moisture content and forward speed on plant damage with different type of blade are presented in Figure 10 to 12, respectively. It was observed that, the plant damage increased as the forward speed increased for all types of blades. During weeding operation less plant damages were observed for all the three types of blades because zone of clearance was provided from crop to blade. Whereas, plant damage was increased during turning. However minimum plant damage was observed at a forward speed of $1.5 \mathrm{~km} \mathrm{~h}^{-1}$ with the $\mathrm{V}$-shape type of blade for all soil moisture contents. Similar findings reported by Mallikarjuna (2017).

Recommended fertilizer application rate of 50 $\mathrm{kg} \mathrm{ha}^{-1}$ was observed at a forward speed of $2.0 \mathrm{~km} \mathrm{~h}^{-1}, 0.078 \mathrm{~ms}^{-1}$ of feed shaft and $3 / 4^{\text {th }}$ of hopper level and these parameters were as considered optimum for applying fertilizer.

The draft increased as the forward speed increased for all types of blades.

Draft was moderate at $14 \%$ moisture content can be considered optimum for carrying out intercutlivation operation.

It was observed that, the weeding efficiency was found to be lower at lower and maximum forward speeds, but it was higher at $2.0 \mathrm{~km} \mathrm{~h}^{-}$ ${ }^{1}$ for all types of blades at all moisture content.

Weeding efficiency was found to be more at soil moisture content of $14 \% \pm 1$ moisture content of the soil for all types of blades.

The weeding efficiency was found to be higher with V-shape type of blade due to its easy penetration ability and self-cleaning ability because of its geometrical shape which has resulted in the increased soil inversion capacity of the blade. Whereas minimum values of weeding efficiency were with crescent type of blade at all soil moisture and forward speeds.

The weeding efficiency of small tractor operated intercultivator cum fertilizer applicator in cotton crop was $89.70 \%$, respectively.

Plants were less damaged during the weeding operation in between rows by using small tractor operated intercultivator cum fertilizer applicator but plant damages was increased while taking the turns at the head land. However the increase in forward speed has increased the per cent of plant damage. The percentage of plant damage due to turns at the head land in cotton was $2.60 \%$, respectively.

Theoretical field capacity of small tractor operated intercultivator cum fertilizer applicator in crop was found to be $0.43 \mathrm{ha} \mathrm{h}^{-1}$.

Effective field capacity of small tractor operated intercultivator cum fertilizer applicator in cotton crop was $0.30 \mathrm{ha} \mathrm{h}^{-1}$, respectively.

Field efficiency of small tractor operated intercultivator cum fertilizer applicator in cotton crop was found as $70.00 \%$, respectively.

\section{References}

Anonymous, 1995, RNAM test codes and procedures for farm machinery, economic and social commission for Asia and Pacific Regional Network for Agriculture machinery, Bangkok, P: 120-152.

Biswas, H. S. and Yadav, G. C., 2004, Animal drawn weeding tools for weeding and intercultural in black soil. Agric. Engg. Today., 28(1-2): 47-53. 
Guruswamy, T., 1985(a), Effect of blade shape on performance of blade hoe for comparative study. Agric. Engg. Today, 12(2): 25-27.

Hunt, D., 1977, farm power and machinery management. Iowa state university, $6^{\text {th }}$ edition. P: 85-99.

Kepner, R. A., Bainer, R. and Barger, E. L., 2005, Principles of Farm Machinery. CBS Publishers \& Distributers (Pvt.) Ltd., New Delhi.

Mallikarjuna, V. R., 2017, Development and performance evaluation of rotary weeder matching to mini tractor. Published Ph.D. (Agril. Engg.) Thesis, Indira Gandhi Krishi Vishwavidhyalaya, Raipur.

Manuwa, S. I., Odubanjo, O. O., Maliumi B. O. and Olfinkua, S. G., 2009, Development and performance evaluation of a row-crop mechanical weeder. J. Engg. Appl. Sci., 4(4): 236239.

Mehta, M. L., Verma, S. R., Mishra, S. R. and Sharma, V. K., 2005, Testing and evaluation of agricultural machinery. Daya Publishing House, Delhi-100 035.

Padole, Y. B., 2007, Performance evaluation of rotary weeder. Agric. Engg. Today., 4(2): 31.

Rajashekar, 2002, Design, development and performance evaluation of tractor drawn multi row rotary weeder. Published M.Tech Thesis, TNAU, Coimbatore.

Sharma, S. and Pannu, C. J. S., 2013, Development and evaluation of a tworow cotton planter with fertilizer applicator. J. Agric. Engg., 50 (3): 3440

Singh, J. and Nikhade, J. S., 2014, Calibration and field performance of seed cum fertilizer drill for paddy cultivation. Int. J. Engg. Sci. Res. Tec., 3(5): 611-615.

Yadav, S. N., Pandey, M. M and Saraswat, D. C., 2007, Effect of design and operating parameters on performance of intercultivation sweep in vertisols. AMA., 38(3): 38-44.

\section{How to cite this article:}

Anandraddi Jumanal, Sushilendra, K.V. Prakash, V. Raghavendra and Yadahalli, G.S. 2018. Effect of Operational Parameters on Performance of Small Tractor Operated Intercultivator cum Fertilizer Applicator in Cotton Crop. Int.J.Curr.Microbiol.App.Sci. 7(11): 2430-2442. doi: https://doi.org/10.20546/ijcmas.2018.711.277 